\title{
Obese Patient-Derived Sera Have Proinflammatory Effect
}

\author{
Lan Yao', Kuan Yan', Yang Xiao', Aimin $\mathbf{X u}^{1}{ }^{2}$, Zhiguang Zhou ${ }^{1}$ and Shiping Liu* ${ }^{1 *}$
}

${ }^{1}$ Diabetes Center, Institute of Metabolism and Endocrinology, Second Xiangya Hospital, Central South University, Changsha, Hunan 410011, China ${ }^{2}$ Medical Department and Pharmacology Department, University of Hong Kong Li Ka Shing Faculty, Hong Kong 999077, China

\begin{abstract}
Aim: Chronic inflammation of adipose tissues plays a key role in obesity-induced metabolic disorders. We examined effects of sera from obese patients with or without different compositions of metabolic disorders on the activation of Toll-like receptor 4 (TLR4)/nuclear factor-kappa B (NF-kB) signaling pathway in the human monocytic leukemia cell line (THP-1), which have never been reported.

Methods: With or without pretreatment of TLR4 monoclonal antibody, THP-1 cells were incubated for 48h by sera from 45 obese patients with or without metabolic disorders and 15 controls. The level of TLR4 in THP-1 cells, intracellular level of phosphorylated NF-KB p65, IL-1 $\beta$ and TNF- $\alpha$ levels in cell culture supernatants were measured.

Results: Compared with controls, the expression level of TLR4, NF-KB p65, IL-1 $\beta$ and TNF- $\alpha$ were significantly increased $(p<0.05)$ after cells were incubated with sera from obese patients. The more compositions of metabolic disorders, the higher increase of these factors. Pretreatment with TLR4 monoclonal antibody suppressed the degree of increase in these factors $(p<0.05)$.

Conclusions: Sera from obese patients could induce the activation of TLR4/NF-KB signaling pathway in THP-1 monocytes by different degrees. The TLR4/NF-KB signaling pathway plays an important role in the proinflammatory effect of obese patient-derived sera.
\end{abstract}

Keywords: Toll-like receptor 4; Obesity; Inflammation; Metabolic disorders

\section{Introduction}

In recent years, numerous studies [1-4] have suggested that for obese patients, the greatest health risk is not fat itself, but rather adipose inflammation. The adipose tissues of obese patients exhibit characteristics of chronic inflammation, and this chronic inflammation of the adipose tissues plays a key role in the occurrence and development of obesity-induced metabolic disorders (e.g., diabetes, and dyslipidemia). Insulin resistance is an important factor in the development of obesity-related diseases, and it is also the driving force for the continuous deterioration observed in individuals afflicted with obesity-related diseases. The cause of insulin resistance is very complex and involves a variety of factors. However, an increasing number of researchers believe that chronic and low grade systemic inflammation, now known as metabolic inflammation (i.e., inflammation initiated by metabolic factors), is the fundamental pathophysiological mechanism of insulin resistance [5]. Metabolic inflammation also plays a vital role in the pathogenesis of obesity-related vascular complications $[2,3]$.

Toll-like receptors (TLRs) are the gating proteins for the transduction of inflammatory signaling. Binding of TLRs with the corresponding ligands triggers signal transduction, leading to the activation of signaling pathways such as the nuclear factor-kappa $\mathrm{B}$ (NF- $\mathrm{BB}$ ), c-Jun amino-terminal kinase (JNK), and P38 mitogenactivated protein kinase (P38 MAPK) pathways, initiation of the transcription of multiple genes associated with inflammatory responses, release of inflammatory mediators, and, eventually, activation of the adaptive immune system [6]. TLR4 was the first mammalian TLR to be identified and is the best-studied member of this family. TLR4 is primarily expressed in lymphoid tissues such as the spleen, peripheral blood leukocytes such as mononuclear phagocytes, dendritic cells, and T and B lymphocytes. TLR4 is also expressed in other tissues, such as the stomach, intestines, lungs, gums, liver, and kidney, and on the surface of a variety of tumor cells and adipocytes. The most basic function of
TLR4 is transmembrane signal transduction, which plays an important role in innate immunity $[7,8]$. TLR4 directly influences adipose tissue macrophage polarization [9], which promotes adipose tissue inflammation and dysfunction. The NF- $\mathrm{kB}$ signaling pathway plays an important role in TLR4-mediated immune regulation [8]. Obesity is associated with the activation of the innate immune pathway, defects in inflammatory responses and the insulin signaling pathway, and insulin resistance [10-12]. TLRs might act as a bridge to link innate immunity, fat metabolism, and insulin resistance $[5,13]$. Activation of the TLR4 signaling pathway in-vivo can induce insulin resistance [14-16].

Adipose tissue is an energy storage tissue, as well as an active endocrine organ. Adipocytes are important locations for the production of pro-inflammatory cytokines, and there is a significant positive correlation between body mass index (BMI) and the concentration of plasma tumor necrosis factor-alpha (TNF-a) [17]. The serum of obese patients has long been a focus of both domestic and international studies, such as those investigating the influence of fatty acids on theophylline binding to human serum albumin obtained from blood from obese patients [18]; the favorable effect of short-term lifestyle intervention on human serum paraoxonase-1 activity and adipokine levels in childhood obesity [19]; the increase in serum levels of fetal antigen 1 (FA1) with obesity; and the negative dependence

*Corresponding author: Shiping Liu, Diabetes Center, Institute of Metabolism and Endocrinology, Second Xiangya Hospital, Central South University, Changsha, Hunan 410011, China, Tel: +86-731-85295845; E-mail: shipingliu119@126.com

Received June 27, 2015; Accepted September 10, 2015; Published September 14,2015

Citation: Yao L, Yan K, Xiao Y, Xu A, Zhou Z, et al. (2015) Obese Patient-Derived Sera Have Proinflammatory Effect. J Diabetes Metab 6: 604 doi:10.4172/21556156.1000604

Copyright: (c) 2015 Yao L, et al. This is an open-access article distributed unde the terms of the Creative Commons Attribution License, which permits unrestricted use, distribution, and reproduction in any medium, provided the original author and source are credited. 
of the insulin sensitivity index on FA1 levels [20]. However, the proinflammatory effects of sera from weight-matched obese patients with different compositions of metabolic disorders and the main underlying proinflammatory pathways have not been reported. This study aimed to detect the proinflammatory effects of sera from obese patients with or without metabolic disorders on a human monocytic cell line and the effects of the TLR4/NF- $\mathrm{KB}$ signaling pathway involved in these proinflammatory effects.

\section{Methods}

\section{Subjects}

Forty-five obese patients with or without metabolic disorders and fifteen normal control individuals were recruited at the Diabetic Center, Metabolism and Endocrinology Institute of Second Xiangya Hospital of Central South University from February to October 2009(The human subject characteristics of each group are shown in Table 1), all the subjects didn't use any medicine. Patients in this study were diagnosed according to the diagnostic criteria from the World Health Organization (WHO) concerning the Asian adult weight classification in the year 2000 . Obesity: BMI $\geq 25 \mathrm{~kg} / \mathrm{m}^{2}$, a waist circumference $\geq 90 \mathrm{~cm}$ for males, and a waist circumference $\geq 80 \mathrm{~cm}$ for females; hyperglycemia: fasting blood glucose $(\mathrm{FBG}) \geq 6.1 \mathrm{mmol} / \mathrm{L}$ or $2-\mathrm{h}$ post-prandial blood glucose $(2-\mathrm{h} P B G) \geq 7.8 \mathrm{mmol} / \mathrm{L}$; dyslipidemia: blood triglyceride (TG) $\geq 1.7 \mathrm{mmol} / \mathrm{L}$ or total cholesterol $(\mathrm{TC}) \geq 5.2$ $\mathrm{mmol} / \mathrm{L}$, high-density lipoprotein-cholesterol (HDL-C) $<1.03 \mathrm{mmol} / \mathrm{L}$ (male) or HDL-C $<1.29 \mathrm{mmol} / \mathrm{L}$ (female), or low-density lipoproteincholesterol $(\mathrm{LDL}-\mathrm{C}) \geq 2.6 \mathrm{mmol} / \mathrm{L}$; and abnormal blood pressure: systolic blood pressure $\geq 140 \mathrm{mmHg}$ or diastolic blood pressure $\geq 90$ $\mathrm{mmHg}$. The subjects met at least one of the following inclusion criteria. Group A (normal control group) included healthy people that were age- and sex-matched to each obese group and had no abnormalities in blood glucose, blood lipids, or blood pressure. Group B, obese group with normal metabolism (ONM). Group C, obese group associated

\begin{tabular}{|c|c|c|c|c|}
\hline & Controls & ONM & OHG & OTD \\
\hline Male:female & $8: 7$ & $10: 5$ & $8: 7$ & $6: 9$ \\
\hline Age (years) & $47 \pm 8$ & $45 \pm 6$ & $51 \pm 7$ & $51 \pm 9$ \\
\hline $\mathrm{BMI}\left(\mathrm{kg} / \mathrm{m}^{2}\right)$ & $22.0 \pm 1.3$ & $27.3 \pm 1.6^{*}$ & $28.7 \pm 2.3^{*}$ & $28.7 \pm 2.6^{\star}$ \\
\hline Waistline $(\mathrm{cm})$ & $79.2 \pm 6.6$ & $90.3 \pm 5.8^{*}$ & $92.8 \pm 6.8^{*}$ & $93.1 \pm 8.7^{\star}$ \\
\hline $\begin{array}{l}\text { Fasting glucose } \\
(\mathrm{mmol} / \mathrm{l})\end{array}$ & $5.14 \pm 0.38$ & $5.11 \pm 0.33$ & $7.76 \pm 1.32^{* \#}$ & $8.07 \pm 3.59^{* \#}$ \\
\hline $\begin{array}{l}2 \mathrm{~h} \text { postprandial } \\
\text { glucose }(\mathrm{mmol} / \mathrm{l})\end{array}$ & $5.28 \pm 0.99$ & $5.79 \pm 1.11$ & $12.25 \pm 3.63^{* \#}$ & $12.63 \pm 6.08^{* \#}$ \\
\hline $\begin{array}{l}\text { Triglyceride } \\
(\mathrm{mmol} / \mathrm{l})\end{array}$ & $1.18 \pm 0.43$ & $1.02 \pm 0.28$ & $1.31 \pm 0.30$ & $1.76 \pm 0.82^{* \# \Delta}$ \\
\hline $\begin{array}{l}\text { Total cholesterol } \\
(\mathrm{mmol} / \mathrm{l})\end{array}$ & $4.58 \pm 0.83$ & $4.35 \pm 0.60$ & $4.53 \pm 0.45$ & $5.40 \pm 1.45^{\star \# \Delta}$ \\
\hline $\begin{array}{l}\text { LDL-cholesterol } \\
(\mathrm{mmol} / \mathrm{l})\end{array}$ & $2.76 \pm 0.48$ & $2.78 \pm 0.50$ & $2.62 \pm 0.65$ & $3.08 \pm 0.99^{*}$ \\
\hline $\begin{array}{l}\text { HDL-cholesterol } \\
(\mathrm{mmol} / \mathrm{l})\end{array}$ & $1.52 \pm 0.31$ & $1.40 \pm 0.25$ & $1.41 \pm 0.27$ & $1.71 \pm 0.16$ \\
\hline $\begin{array}{l}\text { Systolic BP } \\
(\mathrm{mmHg})\end{array}$ & $112 \pm 15$ & $117 \pm 13$ & $114 \pm 13$ & $151 \pm 15^{\star \# \Delta}$ \\
\hline $\begin{array}{l}\text { Diastolic BP } \\
(\mathrm{mmHg})\end{array}$ & $69 \pm 10$ & $75 \pm 10$ & $70 \pm 11$ & $87 \pm 17^{* \# \Delta}$ \\
\hline $\begin{array}{l}\text { Free fat acid } \\
\quad(\mathrm{mmol} / \mathrm{l})\end{array}$ & $0.76 \pm 0.53$ & $1.00 \pm 0.64$ & $0.70 \pm 0.19$ & $0.72 \pm 0.15$ \\
\hline
\end{tabular}

The data are expressed as mean \pm standard deviation (S.D.). ONM: obesity with normal metabolism; OHG: obesity with hyperglycemia; OTD: obesity with three kinds of metabolic disorders. " $p<0.05$ as compared with controls; $" p<0.05$ as compared with ONM; ${ }^{\wedge} p<0.05$ as compared with OHG.

Table 1: Subject characteristics. with hyperglycemia (OHG) . Group D, obese group associated with three kinds of metabolic disorders (OTD) :blood glucose abnormalities, dyslipidemia and abnormal blood pressure. The exclusion criteria were the following: (1) acute and/or chronic inflammation; (2) acute stress conditions (including diabetic ketoacidosis, hyperglycemic and hyperosmolar conditions, trauma, surgery, etc.); (3) autoimmune diseases; (4)type I diabetes; (5) pregnancy or lactation; (6) obvious heart, liver, or kidney disease and neoplastic diseases; (7) significant lesions in medium and large blood vessels, such as coronary heart disease, cerebrovascular accidents, and peripheral arteriosclerosis of the limbs; (8) pathological obesity caused by Cushing's disease, drugs, hypothalamic syndrome, or acromegaly; and (9) patients who could not collaborate. None of the subjects had a smoking or drinking habit. The study was approved by the Hospital Ethics Committee of Central South University, China.

\section{Culture of the human monocytic leukemia cell line (THP-1)}

The THP-1 cell line (a gift from Professor Aimin Xu, Li Ka Shing Faculty of Medicine, University of Hong Kong) was seeded in RPMI 1640 medium containing 10\% fetal bovine serum, $100 \mathrm{U} / \mathrm{ml}$ penicillin, $100 \mu \mathrm{g} / \mathrm{ml}$ streptomycin, and $1 \%$ glutamine and was placed in incubators at $37^{\circ} \mathrm{C}$ with $5 \% \mathrm{CO}_{2}$. The cell intervention experiments were performed when the cells started to grow robustly and entered the exponential growth phase.

\section{Serum treatment and intervention}

Venous blood $(10 \mathrm{ml})$ was collected in the early morning after a 12-hour fasting period. The blood samples were centrifuged (2000 r/ min) within $2 \mathrm{~h}$ to isolate the serum. After a $56^{\circ} \mathrm{C}$ water bath for 30 min to inactivate the complements, the serum was added to RPMI 1640 medium containing $100 \mathrm{U} / \mathrm{ml}$ penicillin, $100 \mu \mathrm{g} / \mathrm{ml}$ streptomycin, and $1 \%$ glutamine for a final concentration of $15 \%$, which was subsequently filtered with $0.22 \mu \mathrm{m}$ microporous filter paper for use. Three duplicated wells were established for each subject as a test group, and $1 \times 10^{6} \mathrm{THP}-$ 1 cells were seeded into 6-well plates. A TLR4 monoclonal antibody (Biolegend, USA) pretreatment group was set up for each test group. The TLR4 monoclonal antibody was added at a concentration of $5 \mu \mathrm{g} /$ $\mathrm{ml}$ to each well for a 30 -min pre-incubation prior to the addition of 2 $\mathrm{ml}$ of RPMI 1640 medium containing 15\% of the intervention serum. After $48 \mathrm{~h}$ of incubation, the cells in each test group were collected for the extraction of protein and mRNA, and the cell culture supernatants were collected by centrifugation and stored in a $-70^{\circ} \mathrm{C}$ refrigerator for subsequent detection of TNF- $\alpha$ and interleukin- 1 beta (IL-1 $\beta$ ).

\section{Western blot analysis of TLR4 protein levels and phosphorylated NF- $\mathrm{kB}$ p65 protein levels in THP-1 cells}

THP-1 cells incubated with serum for $48 \mathrm{~h}$ were collected, washed with pre-cooled phosphate-buffered saline, and centrifuged to remove the saline. Radioimmunoprecipitation assay (RIPA) lysis buffer was then mixed with phenylmethylsulfonyl fluoride (PMSF) at a ratio of 98:2 to lyse cells and extract the proteins. The protein concentration of each group was adjusted to the same level based on analysis with a bicinchoninic acid (BCA) protein assay kit. A 30$\mu \mathrm{g}$ protein sample from each group was added to sodium dodecyl sulfate (SDS) gel-loading buffer at a ratio of $20 \%$, and the gel samples were boiled at $100^{\circ} \mathrm{C}$ for $5 \mathrm{~min}$ before use. The $\beta$-actin in the samples was used as an internal reference. Proteins were separated by SDSPAGE, transferred to a membrane, and then blocked with $10 \%$ fatfree dried milk in TBST (Tris-buffered saline and Tween-20) for $2 \mathrm{~h}$. Based on the different molecular weights of TLR4, NF- $\mathrm{kB}$ p65, and 
$\beta$-actin, the membrane was cut into three parts containing TLR4, $\mathrm{NF}-\kappa \mathrm{B}$ p65, and $\beta$-actin, respectively; the membrane portions were incubated with the corresponding primary antibodies overnight at $4^{\circ} \mathrm{C}$ and with the secondary antibodies for $2 \mathrm{~h}$ at room temperature. This process was followed by enhanced chemiluminescence (ECL) and film exposure, developing, fixing, and scanning for preservation. The membrane containing NF- $\kappa \mathrm{B}$ p65 was immersed by membrane washing solution, then washed on a shaker for $50 \mathrm{~min}$, followed with three 10-min washes by TBST. The membrane was then incubated with rabbit anti-human phospho-NF-kB p65 antibody (ser536) (ABCAM, UK) overnight at $4^{\circ} \mathrm{C}$, followed by incubation with the secondary antibody at room temperature for $2 \mathrm{~h}$. TBST was used to wash the membrane three times for $15 \mathrm{~min}$ each. The washing was followed by the ECL chemiluminescent chromogenic reaction and film exposure, developing, fixing, and scanning for preservation. The grayscale values of the protein bands were determined using ImageJ software. The ratios of the grayscale value of TLR4 to the $\beta$-actin internal control and that of phosphorylated NF- $\kappa B$ p 65 to the $\beta$-actin internal control were used to quantify the expression of TLR4 and NF- $\kappa B$ p 65 , respectively.

\section{Detection of TLR4 mRNA}

TRIzol was used to extract the total RNA of THP- 1 cells after $48 \mathrm{~h}$ of serum intervention. The concentration and purity of RNA was detected by an ultraviolet protein and nucleic acid analyzer. The internal reference was 18s. The design of the primers (provided by Professor Aimin Xu, Li Ka Shing Faculty of Medicine, University of Hong Kong) was as follows: the human TLR4 primer sequence for the sense strand was 5'-AAGCCGAAAGGTGATTGTTG-3' and that of the antisense strand was 5'-CTGAGCAGGGTCTTCTCCAC-3'; the 18 s primer sequence of the sense strand was 5'AGTCCCTGCCCTTTGTACACA-3' and that of the antisense strand was 5'-CGATCCGAG GGCCTCACTA-3'. The one Step SYBR PrimeScript ${ }^{\mathrm{TM}}$ RT-PCR Kit II (Takara, Japan) was used for the PCR reaction, which included two steps, reaction system preparation and the real-time quantitative PCR reaction: (1) the PCR reaction solution was prepared on ice and had the following composition ( $20 \mu \mathrm{l}$ reaction mixture): $10 \mu \mathrm{l}$ of $2 \mathrm{xOne}$ Step RT-PCR buffer III, $0.8 \mu$ l of PrimeScript 1 Step Enzyme Mix II, $0.8 \mu \mathrm{l}$ of the PCR forward primer $(10 \mu \mathrm{M}), 0.8 \mu \mathrm{l}$ of the PCR reverse primer $(10 \mu \mathrm{M}), 2 \mu \mathrm{l}$ of sample RNA, and $5.8 \mu$ of distilled water (RNase-free); and (2) onestep PCR amplification on the LightCycler ${ }^{\circledR}$ Real Time PCR amplifier with the following program: the first reverse transcription reaction step with one cycle of $42^{\circ} \mathrm{C}$ for $5 \mathrm{~min}$ and $95^{\circ} \mathrm{C}$ for $10 \mathrm{~s}$, the second PCR reaction step with 40 cycles of $95^{\circ} \mathrm{C}$ for $15 \mathrm{~s}$ and $60^{\circ} \mathrm{C}$ for $60 \mathrm{~s}$, and the third melting curve analysis step of $95^{\circ} \mathrm{C}$ for $0 \mathrm{~s}, 65^{\circ} \mathrm{C}$ for $15 \mathrm{~s}$, and $95^{\circ} \mathrm{C} 0 \mathrm{~s}$. After the completion of the reaction, the amplification and melting curves were analyzed to obtain the $\mathrm{Ct}$ values. The difference in the $\mathrm{Ct}$ values between the TLR4 gene and $18 \mathrm{~s}, \Delta \mathrm{Ct}$, was calculated, and 2- $\Delta \Delta \mathrm{Ct}$ was used to represent the relative content of TLR4 mRNA.

\section{Determination of IL-1 $\beta$ and TNF- $\alpha$ concentration}

Both IL- $1 \beta$ and TNF- $\alpha$ in culture supernatants were measured with an enzyme-linked immunosorbent assay kit (BD Bioscience, USA) according to the manufacturer's protocol. The minimum detectable doses for IL- 1 and TNF- $\alpha$ were 0.8 and $2 \mathrm{pg} / \mathrm{ml}$, respectively. The intraand inter-assay coefficients of variation for IL- $1 \beta$ were $2.8 \%$ and $4.7 \%$, respectively. The intra- and inter-assay coefficients of variation for TNF- $\alpha$ were $3.7 \%$ and $5.1 \%$, respectively.

\section{Statistical analysis}

Statistical analysis was performed using the statistical package
SPSS Version 13.0. The results were expressed as the mean \pm deviation (S.D.). The statistical analysis involved a one-way analysis of variance (ANOVA) followed by multiple comparisons test. A $p$-value $<0.05$ was accepted as significant difference.

\section{Results}

\section{Subject characteristics}

Compared with the normal control group, all obese groups exhibited a significantly increased BMI and waist circumference $(p<0.05$, Table 1). Compared with ONM, OHG exhibited significantly increased FBG and 2-h PBG $(p<0.05$, Table 1). OTD exhibited significantly higher FBG, 2-h PBG, TG, TC, LDL-C, and systolic and diastolic blood pressures $(p<0.05$, Table 1$)$. So it supports that compared with normal people, obese patients are easier to exist metabolic disorders.

\section{Effects of obese patient-derived sera on TLR4 levels and NF- кB p65 phosphorylation levels in THP-1 cells}

Figure 1 and Table 2 showed the effects of obese patient-derived sera on TLR4 levels and NF- $\mathrm{BB}$ p65 phosphorylation levels in THP1 cells, Table 2 also showed the secretion of inflammatory cytokines (TNF- $\alpha$ and IL-1 $\beta$ ) in THP-1 cells. Figure 1 represented one typical patient of each group, while Table 2 was the whole data of each group.

Figure 1 and Table 2 showed that compared with serum from the normal control group, incubation with serum from ONM led to increased TLR4 mRNA and protein expression in THP-1 cells, increased intracellular NF- $\mathrm{BB}$ p65 phosphorylation, and increased concentrations of inflammatory cytokines (TNF- $\alpha$ and IL-1 $\beta$ ) in the culture supernatant $(p<0.05)$.

Compared with serum from ONM, incubation with serum from OHG and OTD led to enhanced or increased TLR4 mRNA and protein expression, intracellular NF- $\kappa B$ p 65 phosphorylation, and secretion of inflammatory cytokines (TNF- $\alpha$ and IL-1 $\beta)$ in THP- 1 cells $(p<0.05)$.

Compared with serum from OTD, incubation with serum from OHG yielded weakened or suppressed TLR4 mRNA and protein expression levels, intracellular NF- $\mathrm{BB}$ p65 phosphorylation, and secretion of inflammatory cytokines (TNF- $\alpha$ and IL-1 $\beta$ ) in THP-1 cells $(p<0.05)$. Compared with serum from the normal (non-obese) group, the sera from each obese group with or without metabolic disorders activated the TLR4/NF- $\kappa$ B signaling pathway in THP-1 cells after incubation for $48 \mathrm{~h}$, and the sera from OTD caused the highest

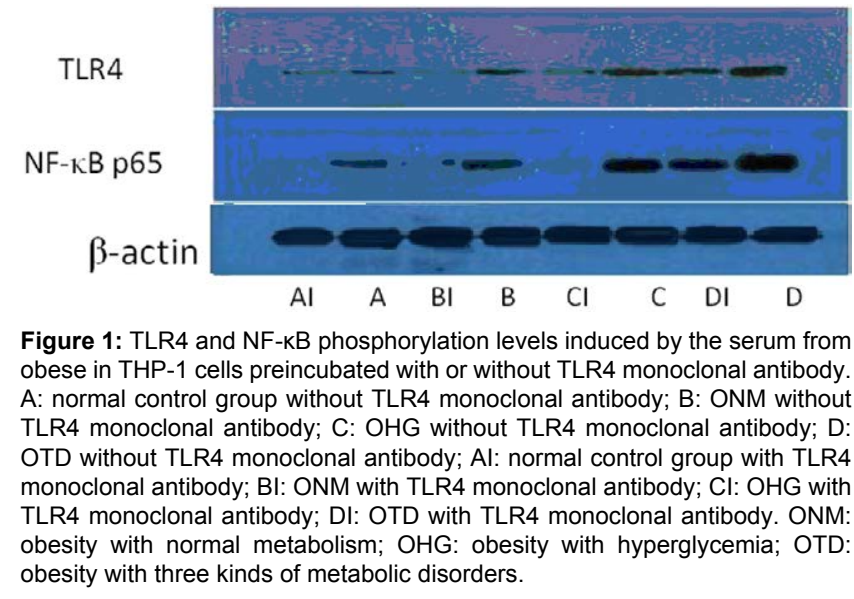




\begin{tabular}{|c|c|c|c|c|c|c|c|c|}
\hline \multirow[b]{2}{*}{$\begin{array}{l}\text { TLR4 antibody } \\
\text { pretreatment }\end{array}$} & \multicolumn{2}{|c|}{ Control } & \multicolumn{2}{|c|}{ ONM } & \multicolumn{2}{|c|}{ OHG } & \multicolumn{2}{|c|}{ OTD } \\
\hline & without & with & without & with & without & with & without & with \\
\hline TLR4 mRNA/18s & $1.03 \pm 0.14$ & $1.07 \pm 0.13$ & $1.43 \pm 0.19^{a}$ & $1.26 \pm 0.14^{\mathrm{a} \star}$ & $2.20 \pm 0.25^{\mathrm{ab}}$ & $2.62 \pm 0.20^{\mathrm{ab} *}$ & $2.15 \pm 0.23^{a b c}$ & $1.44 \pm 0.19^{a b c *}$ \\
\hline TLR4 Protein / $\beta$-actin & $0.16 \pm 0.05$ & $0.15 \pm 0.03$ & $0.28 \pm 0.06^{\mathrm{a}}$ & $0.17 \pm 0.05^{\mathrm{a} *}$ & $0.40 \pm 0.12^{\mathrm{ab}}$ & $0.38 \pm 0.12^{\mathrm{ab} *}$ & $0.85 \pm 0.08^{\mathrm{abc}}$ & $0.19 \pm 0.05^{\mathrm{abc} *}$ \\
\hline $\begin{array}{l}\text { NF-kB p65 protein/ } \beta \text { - } \\
\text { actin }\end{array}$ & $0.16 \pm 0.02$ & $0.13 \pm 0.03$ & $0.26 \pm 0.06^{a}$ & $0.14 \pm 0.03^{a *}$ & $0.44 \pm 0.05^{\mathrm{ab}}$ & $0.19 \pm 0.04^{\mathrm{ab} *}$ & $0.86 \pm 0.07^{\mathrm{abc}}$ & $0.21 \pm 0.08^{\mathrm{abc} *}$ \\
\hline TNF- $\alpha(p g / m l)$ & $225.79 \pm 24.29$ & $226.82 \pm 26.72$ & $253.30 \pm 31.57^{\mathrm{a}}$ & $224.43 \pm 26.71^{\text {a* }}$ & $336.34 \pm 26.55^{\mathrm{ab}}$ & $316.97 \pm 35.75^{\mathrm{ab} *}$ & $456.79 \pm 19.68^{\mathrm{abc}}$ & $412.87 \pm 30.24^{\mathrm{abc} *}$ \\
\hline $\mathrm{IL}-1 \beta(\mathrm{pg} / \mathrm{ml})$ & $135.96 \pm 12.73$ & $133.19 \pm 16.15$ & $253.30 \pm 31.57^{a}$ & $132.78 \pm 23.67^{a^{*}}$ & $197.94 \pm 16.13$ & $183.51 \pm 19.30^{\mathrm{ab} *}$ & $268.74 \pm 14.50^{\mathrm{abc}}$ & $243.05 \pm 19.72^{\mathrm{abc*}}$ \\
\hline
\end{tabular}

Table 2: TLR4, NF-KB phosphorylation levels, TNF- $\alpha$ and IL-1 $\beta$ levels induced by the serum from obese in THP-1 cells preincubated with or without TLR4 monoclonal antibody.

TLR4 expression level and the highest NF- $\kappa B$ p 65 phosphorylation level in THP-1 cells. An intragroup comparison of the obese groups with or without metabolic disorders revealed that an increased serum incubation after $48 \mathrm{~h}$ resulted in enhanced or increased TLR4 mRNA and protein expression, intracellular NF- $\kappa \mathrm{B}$ p 65 phosphorylation, and secretion of inflammatory cytokines (TNF- $\alpha$ and IL-1 $\beta$ ) in the THP-1 cells incubated with sera from OHG and OTD $(p<0.05)$.

\section{The expression level of TLR4, NF- $\mathrm{B}$ p65, IL-1 $\beta$ and TNF- $\alpha$ after pretreatment with the TLR4 monoclonal antibody}

After pretreatment with the TLR4 monoclonal antibody, with the exception of the normal control group, TLR4 protein expression, intracellular NF- $\kappa \mathrm{B}$ p 65 phosphorylation levels, and the secretion of inflammatory cytokines (TNF- $\alpha$ and IL-1 $\beta$ ) were all weakened or suppressed in the other three group.

\section{Discussion}

Obesity is a chronic inflammatory disease [21-24]. Macrophage infiltration is increased in the white adipose tissue of obese patients, and TLR4 expression is increased in adipocytes [22] and muscle tissue [25]. A previous study [26] has suggested direct effects of saturated fatty acids (SFAs) on inflammasome activation via TLR4. FFAs can activate the TLR4 receptors of adipocytes and macrophages, and the inflammatory effect of FFAs is blocked in TLR4-deficient cells [27]. In addition, lipopolysaccharide(LPS) inhibits beta-cell gene expression in a TLR4-dependent manner and via NF- $\kappa B$ signaling in pancreatic islets [28]. Inhibition of TLR4 reduces hypothalamic inflammation, accompanied by a reduction in hypothalamic resistance to leptin and improved insulin signal transduction in the liver [29]. These findings suggest that the TLR4 signaling pathway is activated in patients with obesity and that the activation of the TLR4/NF- $\kappa \mathrm{B}$ signaling pathway might damage the function of pancreatic islet beta cells, while the inhibition of the TLR4 signaling pathway might improve insulin signal transduction. Our findings suggest that obese patient-derived serum can induce pro-inflammatory effects by activating TLR4/NF- $\kappa B$ signaling in THP-1 cells, and the effect is strongly associated with the degree of metabolic disorders. To explore the role of the TLR4/NF$\mathrm{\kappa B}$ signaling pathway in the proinflammatory effect produced by sera from obese patients, we utilized a TLR4 monoclonal antibody to block the TLR4/NF- $\mathrm{kB}$ signaling pathway in the THP-1 monocytic cell line before the 48-h incubation with the obese patient-derived sera (Figure 1 , Table 2), followed by measurement of the levels of the inflammatory cytokines TNF- $\alpha$ and IL- $1 \beta$ in the culture supernatant. Both TNF- $\alpha$ and IL-1 $\beta$ levels were decreased (Table 2 ), suggesting that the TLR4/ $\mathrm{NF}-\kappa \mathrm{B}$ signaling pathway plays a relatively important role in the proinflammatory effect on THP-1 cells produced by sera from obese patients with or without metabolic disorders.
TLR4 is type 1 transmembrane protein, the basic function is transmembrane conductance of the signal. TLR4 can widely specifically recognize Pathogen-associated molecular patterns and related endogenous ligand (in the case of stress, injury and non-apoptotic cell death, the body produces some endogenous molecules), coupled signal transduction pathways, active innate immune cells and inflammatory cells, eventually lead to a series of immune and inflammatory response, which can cause the synthesis and release of cytokines and inflammatory mediators, prompting the immune cell maturation, differentiation and function, involved in the body's resistance to infection, anti-tumor and immune and inflammatory injury. TLRs has many endogenous ligands [30-33]. High glucose levels can activate the TLR4/NF- $\kappa B$ signaling pathway on the surface of the THP-1 monocytic cell line, leading to increased levels of inflammatory cytokines in the cell culture supernatant. Triglycerides in the serum can activate the TLR4/NF$\kappa \mathrm{B}$ signaling pathway and increase the expression of inflammatory cytokines. Palmitic acid can activate TLR4 expression on the surface of 3T3-L1 adipocytes, resulting in increased chemokine expression. However, this effect can be blocked by polyunsaturated fatty acids $[30,34]$. TLR4 mediates the proinflammatory effect of angiotensin II (Ang II) [35]. FFAs exacerbate high glucose-induced TLR expression and activity in monocytic cells with excess superoxide release, enhanced NF- $\kappa B$ activity, and induced proinflammatory factor release [36]. The above information supports the results of this study, which indicate that the sera from obese patients with more compositions of metabolic disorders had a stronger effect in activating the TLR4/NF- $\kappa B$ signaling pathway in THP-1 cells.

We also observed that the TLR4 monoclonal antibody could not completely prevent the increase in the levels of released IL- $1 \beta$ and TNF- $\alpha$ in the cell culture supernatant, suggesting that the obese patient-derived sera might activate other inflammatory pathways in addition to the TLR4 signaling pathway to increase the expression of inflammatory cytokines. The activation of several serine/threonine kinases such as JNK, protein kinase c (PKC), IKB kinase (IKK), and suppressors of cytokine signaling (SOCS) is observed in the adipose tissue of obese patients, resulting in an increase in downstream inflammatory cytokines [37].

In recent years, adipose tissue, particularly visceral adipose tissue, has been recognized as a very important endocrine organ, it can secrete many adipokines and cytokines. Compared to people of normal weight, obese patients exhibit differences in metabolites related to branchedchain amino acids, body composition, adipokines, hormone levels, growth hormone axis, inflammatory cytokines, and fatty acid profile [38]. Significantly reduced adiponectin levels in obese patients in-vivo can block the FFA-mediated activation of the TLR4 signaling pathway in monocytes. Although our study excluded the effect of infections 
and severe stress responses and matched serum FFA levels, the serum from the obese group with normal metabolism more strongly activated the TLR4/NF- $\mathrm{KB}$ inflammatory pathway in THP-1 cells compared with the non-obese group with normal metabolism (Figure 1, Table 2 ). In addition to the traditional metabolites from glucose and lipid metabolism, there may be other influencing factors in the sera of obese patients, such as hormone levels, cytokines, amino acids, and fatty acids, that can activate the TLR4/NF- $\mathrm{kB}$ inflammatory pathways in THP-1 cells. This hypothesis needs to be confirmed by further in-depth studies.

Activation of the TLR4/NF-kB signaling pathway can directly affect the progress of insulin-mediated signaling transduction, induce and aggravate insulin resistance, and cause obesity-related diseases (diabetes, hypertension, and dyslipidemia). It can also act on endothelial cells, causing endothelial cell damage and stimulating the proliferation of vascular smooth muscle cells and thus promoting the occurrence and development of atherosclerosis and vascular events. Therefore, inhibition of the TLR4/NF- $\kappa B$ signaling pathwaydependent inflammatory reaction can reverse the development of insulin resistance and atherosclerosis $[7,13,39]$.

In summary, our results suggest that for the prevention and treatment of obesity-related diseases and vascular lesions in obese patients, it is necessary to suppress or eliminate factors that activate the TLR4/NF- $\kappa B$ signaling pathway. Weight loss should be emphasized for obese patients with a normal metabolism, while for obese patients with metabolic disorders, existing metabolic disorders should be treated [40] in addition to weight loss [32].

\section{Acknowledgements}

This work was supported by grants from Hunan Provincial scientific plan of China (No.fj 3019).

\section{Conflict of Interest}

The authors have not declared any conflicts of interest.

\section{References}

1. Miranville A, Herling AW, Biemer-Daub G, Voss MD (2012) Differential adipose tissue inflammatory state in obese nondiabetic Zucker fatty rats compared to obese diabetic zucker diabetic fatty rats. Horm Metab Res 44: 273-278.

2. Shoelson SE, Herrero L, Naaz A (2007) Obesity, inflammation, and insulin resistance. Gastroenterology 132: 2169-2180.

3. Berg AH, Scherer PE (2005) Adipose tissue, inflammation, and cardiovascular disease. Circ Res 96: 939-949.

4. Wu H, Ghosh S, Perrard XD, Feng L, Garcia GE, et al. (2007) T-cell accumulation and regulated on activation, normal $T$ cell expressed and secreted upregulation in adipose tissue in obesity. Circulation 115: 1029-1038.

5. Shoelson SE, Lee J, Goldfine AB (2006) Inflammation and insulin resistance. J Clin Invest 116: 1793-1801.

6. Medzhitov R, Preston-Hurlburt P, Janeway CA Jr (1997) A human homologue of the Drosophila Toll protein signals activation of adaptive immunity. Nature 388: 394-397.

7. Shi H, Kokoeva MV, Inouye K, Tzameli I, Yin H, et al. (2006) TLR4 links innate immunity and fatty acid-induced insulin resistance. J Clin Invest 116: 30153025 .

8. Akira S, Takeda K (2004) Toll-like receptor signalling. Nat Rev Immunol 4: 499511.

9. Orr JS, Puglisi MJ, Ellacott KL, Lumeng CN, Wasserman DH, et al. (2012) Tolllike receptor 4 deficiency promotes the alternative activation of adipose tissue macrophages. Diabetes 61: 2718-2727.

10. Roden M, Price TB, Perseghin G, Petersen KF, Rothman DL, et al. (1996) Mechanism of free fatty acid-induced insulin resistance in humans. J Clin Invest 97: 2859-2865
11. Shoelson SE, Lee J, Yuan M (2003) Inflammation and the IKK beta/l kappa B/NF-kappa B axis in obesity- and diet-induced insulin resistance. Int J Obes Relat Metab Disord 27 Suppl 3: S49-52.

12. Hotamisligil GS (2003) Inflammatory pathways and insulin action. Int J Obes Relat Metab Disord 27 Suppl 3: S53-55.

13. Kim F, Pham M, Luttrell I, Bannerman DD, Tupper J, et al. (2007) Toll-like receptor-4 mediates vascular inflammation and insulin resistance in dietinduced obesity. Circ Res 100: 1589-1596.

14. Tsukumo DM, Carvalho-Filho MA, Carvalheira JB, Prada PO, Hirabara SM et al. (2007) Loss-of-function mutation in Toll-like receptor 4 prevents dietinduced obesity and insulin resistance. Diabetes 56: 1986-1998.

15. Milanski M, Degasperi G, Coope A, Morari J, Denis R, et al. (2009) Saturated fatty acids produce an inflammatory response predominantly through the activation of TLR4 signaling in hypothalamus: implications for the pathogenesis of obesity. J Neurosci. 29: 359-70

16. Reyna SM, Ghosh S, Tantiwong P, Meka CS, Eagan P, et al. (2008) Elevated toll-like receptor 4 expression and signaling in muscle from insulin-resistant subjects. Diabetes 57: 2595-2602.

17. Olszanecka-Glinianowicz M, Zahorska-Markiewicz B, Janowska J, Zurakowsk A (2004) Serum concentrations of nitric oxide, tumor necrosis factor (TNF)alpha and TNF soluble receptors in women with overweight and obesity. Metabolism. 53: 1268-73.

18. Maciazek-Jurczyk M, Sulkowska A, Bojko B, Równicka-Zubik J, Szkudlarek Hasnik A, et al. (2012) The influence of fatty acids on theophylline binding to human serum albumin. Comparative fluorescence study. Spectrochim Acta $A$ Mol Biomol Spectrosc. 89: 270-5

19. Koncsos P, Seres I, Harangi M, Páll D, Józsa L, et al. (2011) Favorable effect of short-term lifestyle intervention on human paraoxonase-1 activity and adipokine levels in childhood obesity. J Am Coll Nutr 30: 333-339.

20. Hotamisligil GS, Shargill NS, Spiegelman BM (1993) Adipose expression of tumor necrosis factor-alpha: direct role in obesity-linked insulin resistance. Science 259: 87-91.

21. Chacón MR, Miranda $M$, Jensen $\mathrm{CH}$, Fernández-Real JM, Vilarrasa $\mathrm{N}$, et al (2008) Human serum levels of fetal antigen 1 (FA1/Dlk1) increase with obesity, are negatively associated with insulin sensitivity and modulate inflammation in-vitro. Int J Obes (Lond). 32:1122-9.

22. Ghanim H, Aljada A, Hofmeyer D, Syed T, Mohanty P, et al. (2004) Circulating mononuclear cells in the obese are in a proinflammatory state. Circulation 110 1564-1571.

23. Alhusaini S, McGee K, Schisano B, Harte A, McTernan P, et al. (2010) Lipopolysaccharide, high glucose and saturated fatty acids induce endoplasmic reticulum stress in cultured primary human adipocytes: Salicylate alleviates this stress. Biochem Biophys Res Commun. 397: 472-8.

24. Zhang HM, Chen LL, Wang L, Xu S, Wang X, et al. (2009) Macrophage infiltrates with high levels of Toll-like receptor 4 expression in white adipose tissues of male Chinese. Nutr Metab Cardiovasc Dis 19: 736-743.

25. Reyna SM, Ghosh S, Tantiwong P, Meka CS, Eagan P, et al. (2008) Elevated toll-like receptor 4 expression and signaling in muscle from insulin-resistant subjects. Diabetes 57: 2595-2602.

26. Reynolds CM, McGillicuddy FC, Harford KA, Finucane OM, Mills KH, et al. (2012) Dietary saturated fatty acids prime the NLRP3 inflammasome via TLR4 in dendritic cells-implications for diet-induced insulin resistance. Mol Nutr Food Res 56: 1212-1222.

27. Shi H, Kokoeva MV, Inouye K, Tzameli I, Yin H, et al. (2006) TLR4 links innate immunity and fatty acid-induced insulin resistance. J Clin Invest 116: 30153025 .

28. Amyot J, Semache M, Ferdaoussi M, Fontés G, Poitout V (2012) Lipopolysaccharides impair insulin gene expression in isolated islets of Langerhans via Toll-Like Receptor-4 and NF-Î'B signalling. PLoS One 7 : e36200.

29. Milanski M, Arruda AP, Coope A, Ignacio-Souza LM, Nunez CE, et al. (2012) Inhibition of hypothalamic inflammation reverses diet-induced insulin resistance in the liver. Diabetes 61: 1455-1462.

30. Xu XH, Shah PK, Faure E, Equils O, Thomas L, et al. (2001) Toll-like receptor-4 is expressed by macrophages in murine and human lipid-rich atherosclerotic plaques and upregulated by oxidized LDL. Circulation 104: 3103-3108. 
Citation: Yao L, Yan K, Xiao Y, Xu A, Zhou Z, et al. (2015) Obese Patient-Derived Sera Have Proinflammatory Effect. J Diabetes Metab 6: 604. doi:10.4172/2155-6156.1000604

Page 6 of 6

31. Ohashi K, Burkart V, Flohé S, Kolb H (2000) Cutting edge: heat shock protein 60 is a putative endogenous ligand of the toll-like receptor-4 complex. J Immunol 164: 558-561.

32. Dasu MR, Devaraj S, Zhao L, Hwang DH, Jialal I (2008) High glucose induces toll-like receptor expression in human monocytes: mechanism of activation. Diabetes 57: 3090-3098.

33. Smiley ST, King JA, Hancock WW (2001) Fibrinogen stimulates macrophage chemokine secretion through toll-like receptor 4. J Immunol 167: 2887-2894.

34. Fessler MB, Rudel LL, Brown JM (2009) Toll-like receptor signaling links dietary fatty acids to the metabolic syndrome. Curr Opin Lipidol 20: 379-385.

35. Ji Y, Liu J, Wang Z, Liu N (2009) Angiotensin II induces inflammatory response partly via toll-like receptor 4-dependent signaling pathway in vascular smooth muscle cells. Cell Physiol Biochem 23: 265-276.

36. Dasu MR, Jialal I (2011) Free fatty acids in the presence of high glucose amplify monocyte inflammation via Toll-like receptors. Am J Physiol Endocrino Metab 300: E145-154.

37. Zick Y (2003) Role of Ser/Thr kinases in the uncoupling of insulin signaling. Int J Obes Relat Metab Disord 27 Suppl 3: S56-60.

38. Newgard CB, An J, Bain JR, Muehlbauer MJ, Stevens RD, et al. (2009) A branched-chain amino acid-related metabolic signature that differentiates obese and lean humans and contributes to insulin resistance. Cell Metab 9: 311-326.

39. Kim F, Pham M, Luttrell I, Bannerman DD, Tupper J, et al. (2007) Toll-like receptor-4 mediates vascular inflammation and insulin resistance in dietinduced obesity. Circ Res 100: 1589-1596.

40. Carpenter KC, Strohacker K, Breslin WL, Lowder TW, Agha NH, et al. (2012) Effects of exercise on weight loss and monocytes in obese mice. Comp Med 62: 21-26. 